\title{
Temporal variations in the diet of the exotic rainbow trout (Oncorhynchus mykiss) in an Andean-Patagonian canopied stream
}

\author{
Variación temporal en la dieta de la trucha exótica arco iris (Oncorhynchus mykiss) \\ en un arroyo forestado de los Andes patagónicos
}

LEONARDO M. BURIA*, RICARDO J. ALBARIÑO, BEATRIZ E. MODENUTTI \& ESTEBAN G. BALSEIRO

Laboratorio de Limnología, INIBIOMA, Universidad Nacional del Comahue, CONICET, Quintral 1250, 8400 Bariloche, Argentina

*e-mail for correspondence: lburia@crub.uncoma.edu.ar

\begin{abstract}
We examined seasonal and diel variation in prey species composition and biomass in the diet of the exotic rainbow trout Oncorhynchus mykiss (Walbaum, 1972). The study was carried out in the upper-forested sections of a low order stream in Andean-Patagonia. We studied the importance of functional feeding groups of aquatic invertebrates and the relative contribution of terrestrial and aquatic prey items in order to assess the pathways connecting terrestrial and aquatic ecosystems along a stream food web. Trout fed on approximately 40 invertebrate species and scrapers were consistently selected, suggesting their increased vulnerability to predation. However in terms of biomass, rainbow trout diet was mostly composed by shredders which emphasized the role of the allochthonous plant detritus pathway in food webs of forested small streams. Trout individuals fed more intensively in spring and summer and during daytime. Terrestrial items constituted a minor proportion of the diet implying that this component did not represent a significant subsidy for this fish population. As a consequence, the top-down effect on the aquatic community does not appear to be dampened since trout do not strongly preyed on terrestrial invertebrates.
\end{abstract}

Key words: allochthonous plant detritus, fish predation, terrestrial and aquatic prey, functional feeding groups.

\section{RESUMEN}

Se estudió la variación estacional y diaria en la composición y biomasa de las especies presa en la dieta de la exótica trucha arco iris Oncorhynchus mykiss (Walbaum, 1972) en la sección superior de un arroyo boscoso de bajo orden en los Andes patagónicos. Se analizó la importancia de los grupos funcionales alimentarios de invertebrados acuáticos y la contribución relativa de las presas de origen terrestre y acuático para evaluar las vías tróficas que conectan los ecosistemas acuático y terrestre circundantes. Las truchas consumieron aproximadamente unas 40 especies de invertebrados y los raspadores fueron consistentemente seleccionados, sugiriendo una alta vulnerabilidad a la depredación. Sin embargo en términos de biomasa, la dieta de la trucha arco iris fue mayormente compuesta de fragmentadores, enfatizando así el papel del detrito vegetal alóctono dentro de las tramas tróficas de pequeños arroyos boscosos. Los ejemplares de trucha capturados se alimentaron con mayor intensidad en primavera y verano y durante las horas del día. Los ítemes terrestres constituyeron una porción minoritaria en la dieta sugiriendo que este componente no representa un subsidio significativo para esta población de peces. Como consecuencia, los efectos del control "desde arriba" ("topdown") en la comunidad acuática no parecen ser amortiguados ya que las truchas no consumen intensamente presas de origen terrestre.

Palabras clave: detrito vegetal alóctono, peces depredadores, presas terrestres y acuáticas, grupos funcionales alimentarios.

\section{INTRODUCTION}

Stream dynamics are generally regarded as occurring at the interface of aquatic and terrestrial ecosystems, where food webs are influenced by both autochthonous primary production and allochthonous inputs from the terrestrial landscape (Naiman \& Decamps 
1997). In small streams flowing through forests, terrestrial plant detritus is generally believed to support the basis of food webs (Petersen \& Cummins 1974, Cummins et al. 1989, Wallace et al. 1997). Allochthonous organic matter is an important energy source to aquatic detritivorous invertebrates (Hieber \& Gessner 2002), and indirectly to predatory fish through invertebrate secondary production (Cummins et al. 1995, Wallace et al. 1997). Nevertheless fish receives the input of terrestrial arthropods that accidentally fall into streams or return to oviposit (Garman 1991, Cloe \& Garman 1996). In temperate systems, it represents a potential source of energy during summer-autumn when biomass of benthic stream invertebrates declines (Nakano \& Murakami 2001). This net subsidy may be significant to the extent of releasing predation pressure on aquatic invertebrates (Nakano et al. 1999) as they may represent a large proportion of the invertebrate mass ingested by fish (Kawaguchi \& Nakano 2001). Fluxes of terrestrial invertebrates into streams can provide up to half the annual energy budget to drift feeding fishes such as salmonids, despite the fact that input occurs differentially along the year (Kawaguchi \& Nakano 2001, Nakano \& Murakami 2001, Baxter et al. 2005).

The knowledge of predator diets is a basal topic to understand predator-prey interactions and the direct and indirect effects on food webs. Despite the importance of fish as top predators in aquatic systems the diet of many fishes is poorly known, especially concerning the indirect significance of detritus and primary production in their secondary production (Lemke \& Bowen 1998). Studies in lotic systems have demonstrated that fish predation significantly alter ecosystem processes mediated by top down effects by strongly affecting particular vulnerable taxonomic or functional components of the community (Power 1990, Huryn 1998, Nakano et al. 1999, Greig \& McIntosh 2006).

In Patagonia, the introduction of salmonid species was a common practice starting early in the twentieth century (Hurlbert et al. 1986, Quirós 1990). At the present, rainbow trout ( $O$. mykiss) has resident populations in low order streams of Patagonia, being an important economic resource for recreational fishery (Pascual et al. 2002, Palma et al. 2002). The study of the diet of rainbow trout in these canopied streams is critical to understand its role as an exotic top predator in food webs. Andean-Patagonia headwater streams are densely shaded by deciduous endemic Nothofagus forests that represent the bulk of leaf litter inputs (Albariño \& Balseiro 2002).

Our main goal was to analyze the diet of $O$. mykiss in terms of the annual differences in prey species composition and abundance of functional feeding groups. We also aimed to compare trout diet with ambient abundance in a diel basis at the time when predation rate was higher (spring). In addition, we aimed to compare the relative contribution of terrestrial vs. aquatic prey to assess the strength of land water connectivity in terms of trout energy subsidy. As trout are opportunistic feeders we expected contrasting patterns in their diet throughout the year following changes in aquatic and terrestrial prey availability. We hypothesized that terrestrial prey items play a major role in trout diet during spring-summer when terrestrial prey abundance is higher.

\section{MATERIAL AND METHODS}

The study was carried out in Challhuaco stream, a low order stream belonging to the Limay river system (Atlantic-slope basin). The study area is located in the Nahuel Huapi National Park, Northwestern Patagonia (Argentina). The area of Challhuaco headwaters correspond to a deciduous forest of Nothofagus pumilio (P. et E.) Krasser ("lenga"). The climate is cold temperate, with a mean annual temperature of $8{ }^{\circ} \mathrm{C}$. Annual precipitations average $1,900 \mathrm{~mm}$ year ${ }^{-1}$ (Barros et al. 1983) with peaks during autumn-winter, falling as rain and snow, while the summer is dry and cool.

The stream bottom is composed by bouldercobble substrates and the stream channel has alternated riffle-pool habitats. During the study, water velocity ranged $0.24-0.84 \mathrm{~m} \mathrm{~s}^{-1}$ and conductivity was low, varying between 25 and $64 \mu \mathrm{S} \mathrm{cm} \mathrm{cm}^{-1}$. The $\mathrm{pH}$ was circumneutral, and dissolved oxygen concentration was always near saturation levels. Sampling sites were located in sections $1.5-2.5 \mathrm{~m}$ wide and 0.12$0.42 \mathrm{~m}$ deep. Water temperature varied greatly during the study, from $11{ }^{\circ} \mathrm{C}$ in summer to $2{ }^{\circ} \mathrm{C}$ 
in winter. In Challhuaco headwaters, fishes are represented by a single species, the exotic rainbow trout (O. mykiss).

The sampling program involved two different schedules. We performed a seasonal sampling during 2003-2004 and additionally a diel sampling in spring 2005. Fishes were captured by electrofishing (with a backpack unit Model 12, Smith-Root Inc., USA) during each study period (seasonal and diel). Seasonal sampling was performed in early September 2003 (winter), late November 2003 (spring), early March 2004 (summer) and mid May 2004 (autumn). The sampling date in winter was determined by logistic conditions (i.e. inaccessibility to sampling sites). Afterwards date samplings were spaced evenly to reflect the seasonal pattern. All seasonal samplings were carried out at daylight between 11 and 15 h. All fish caught were identified and fork length measured to the nearest millimeter. After capture, fishes were immediately killed, to avoid post-capture digestion of prey items, and preserved in $5 \%$ formalin. In the laboratory, the stomach of each individual fish was removed and preserved in $70 \%$ ethanol. Stomach content analysis was performed under stereoscopic microscope. Prey items (both aquatic and terrestrial) were sorted, counted and identified to the lowest possible taxonomic level. Prey identification was feasible by comparing digestion-resistant body parts (e.g., head capsules, body sclerites) with those of entire individuals. Aquatic invertebrates prey were assigned to functional feeding groups (FFGs) based on gut insect analyses and literature references (Merritt \& Cummins 1996, Albariño \& Balseiro 2002, Velázquez \& Miserendino 2003, Albariño \& Díaz Villanueva 2006). Total body length of each individual prey was measured with an ocular micrometer, to the nearest $0.1 \mathrm{~mm}$, and prey invertebrate biomass was estimated based on specific length-mass regressions (Miserendino 2001). When regressions were unavailable, a set of individuals ( $>30$ ) covering the body length range of selected species were measured, dried at $80{ }^{\circ} \mathrm{C}$ for $24 \mathrm{~h}$, weighed at the nearest 0.01 $\mathrm{mg}$ and used to estimate biomass vs. body length relationships.

Seasonal natural prey abundances were studied in benthic samples. Ten Surber samples $\left(0.09 \mathrm{~m}^{2}, 250 \mu \mathrm{m}\right.$ mesh size $)$ were collected randomly at midday on each season in run-riffle habitats where substrate was a mixture of boulders and cobbles. Samples were collected at least $24 \mathrm{~h}$ previous to fish sampling to allow trout to return to natural foraging behavior. Additionally, a diel periodicity survey to assess invertebrate drift and trout diet along a $24 \mathrm{~h}$ period (every $6 \mathrm{~h}$ ) was carried out on one day in late spring. This was decided considering that trout showed to feed more actively in spring and summer (see results) and that terrestrial insect activity is also higher at this period in temperate biomes. This study was carried out placing at the entrance of a pool a set of three drift nets $(250$ $\mu \mathrm{m}$ mesh size; $0.3 \times 0.3 \mathrm{~m}$ opening at the mouth) therefore covering $90 \mathrm{~cm}$ of stream section. Frames for fixing the drift nets were placed two days before the sampling was carried out. The wetted channel area was divided transversally into three subsections (left, centre, and right) and drift nets were positioned to intercept water column and surface in each subsection. The nets were deployed for $50 \mathrm{~min}$ at 6-h intervals $(06: 00,12: 00,18: 00$, and 24:00 h) over a $24 \mathrm{~h}$ period on December 22, 2005, where 6:00 and 24:00 corresponded to drift under dawn and dark conditions, respectively. Electrofishing was performed downstream the drift sampling site immediately after collecting drift samples to avoid interference between predation and drift estimates. Previously to this study, we established that net clogging did not occur during the elapsed drift collecting time. All samples were preserved in $70 \%$ ethanol until examination. Terrestrial invertebrates caught in drift nets were used as an estimate of availability for trout. This sampling allowed us to assess the relative abundance of aquatic and terrestrial prey in the water column and stream surface.

Finally, at each sampling date, we compared the frequency of a particular prey species and a FFG in the diet and in the environment. In the seasonal sampling, only aquatic insects were considered as we used benthic invertebrate abundances as subrogate of prey availability, while in the diel analysis, both aquatic and terrestrial prey species (corresponding to drift sampling) were evaluated. We plotted the percentage abundance of each main food item in trout stomachs against that of the same species in the benthic habitat (seasonal sampling) or in the drift (diel sampling). If 
trout would prey in the same proportion to invertebrate relative ambient abundance the points should fall along the 1:1 line.

Statistical analyses were performed to assess differences in prey abundance (i.e. prey number and prey types) in trout stomachs among seasons or time of the day. Normality and homocedasticity were checked and data were log-transformed when needed to fulfill ANOVA requirements; otherwise the Kruskal-Wallis test was used to compare results. A factorial analysis (two-way ANOVA) was performed to test differences between prey types (i.e., terrestrial versus aquatic or among aquatic FFGs) and seasons. We performed the same factorial analysis comparing prey type vs. time of the day (diel sampling). Multiple comparisons were performed using Tukey (ANOVA) and Dunn (Kruskal-Wallis) post hoc tests.

\section{RESULTS}

Almost all trout collected $(n=190)$ were found with food in their guts and the number of prey per stomach ranged from cero (two individuals in autumn) to 95 specimens. Significant variation was found in the observed average number of prey per stomach among seasons (Kruskal-Wallis test, $\mathrm{H}_{3}=43,297, \mathrm{P}<0.001$ ) and also along the spring diel sampling $\left(\right.$ ANOVA, $\mathrm{F}_{3,51}=3.891, \mathrm{P}=0.014$; Table 1). Rainbow trout fed significantly more actively during spring and summer than in autumn and winter (Dunn's test, $\mathrm{P}<0.05$ ). In spring, diel variation showed that mean prey per stomach was markedly lower at dawn and night (Tukey test, $\mathrm{P}<0.05)$, and peaked at daytime $(12: 00$ 18:00 h) with higher feeding activity at noon and before dusk, suggesting a great light dependence.

Trout diet included near 40 species of invertebrates, without recording any vertebrate remain (e.g., amphibians or fish). Aquatic invertebrates significantly dominated, both in abundance and biomass, compared with terrestrial prey but their importance in the diet changed seasonally (two-way ANOVA interaction term, $\mathrm{P}<0.001$, Table 2, Fig. 1). Absolute abundance and biomass of aquatic prey in the diet significantly increased in spring (Tukey's test, $\mathrm{P}<0.05$ ), however, for terrestrial invertebrates they did not change among seasons (Tukey's test, $\mathrm{P}>0.05$ ). Along the year, terrestrial items represented only 5 and $4 \%$ of total prey number and biomass, respectively. The diet analysis of the diel sampling also showed that trout significantly consumed more aquatic than terrestrial prey but their importance in terms of prey numbers changed along the day (two-way ANOVA interaction term, $\mathrm{P}=0.033$, Table 2, Fig. 1). More aquatic prey, in terms of

TABLE 1

Fish total length and mean number of prey per fish in rainbow trout collected in Challhuaco stream. Values are given as means (and SE).

Longitud total y número medio de presas por pez en las truchas arco iris colectadas en el arroyo Challhuaco. Los valores están expresados como promedios (y EE).

\begin{tabular}{|c|c|c|c|c|}
\hline & Number of trouts sampled & Mean length $(\mathrm{cm})$ & Range $(\mathrm{cm})$ & Number of prey per fish \\
\hline \multicolumn{5}{|c|}{ Seasonal sampling } \\
\hline Summer & 33 & $10.9(0.5)$ & $8.9-17.5$ & $21.1(3.3)$ \\
\hline Autumn & 30 & $11.1(0.4)$ & $8.1-15.8$ & $7.6(1.0)$ \\
\hline Winter & 37 & $9.8(0.7)$ & $7.2-17.0$ & $14.7(0.7)$ \\
\hline Spring & 28 & $11.6(0.3)$ & $9.4-15.9$ & $34.7(4.0)$ \\
\hline \multicolumn{5}{|c|}{ Diel sampling } \\
\hline 06:00 & 15 & $9.6(0.3)$ & 8.6-11.4 & $22.8(3.1)$ \\
\hline $12: 00$ & 15 & $10.7(0.6)$ & $8.4-14.9$ & $34.5(5.1)$ \\
\hline 18:00 & 17 & $9.5(0.8)$ & $6.7-18.0$ & $35.6(4.4)$ \\
\hline $24: 00$ & 15 & $9.3(0.8)$ & $8.0-10.9$ & $20.9(2.8)$ \\
\hline
\end{tabular}


numbers and biomass, were consumed at daylight (12:00 - 18:00 h) (Tukey's test, $\mathrm{P}<$ 0.05 , Table 2). In contrast, terrestrial prey consumption did not differ statistically along the day (Tukey's test, $\mathrm{P}>0.05$, Fig. 1). However, the relative proportion of those items doubled at midnight (Fig. 1. $37 \%$ of total prey number) compared to daylight (18\%).

Shredders were the most abundant FFG in the diet of rainbow trout during the year (Fig. 2). However, their relative importance differed significantly among seasons (two-way ANOVA, prey type $\mathrm{x}$ season $\mathrm{P}=0.003$, Fig. 2, Table 3). The biomass of shredders in trout diet was significantly higher than the other FFGs in winter and spring (Tukey's test, $\mathrm{P}<0.05$ ) while in the summer and autumn shredders codominated with scrapers (40 and $30 \%$ of relative biomass, respectively).

The diel analysis of aquatic prey foraged by trout indicated that shredders were significantly more consumed than the other FFGs except scrapers (two-way ANOVA, $\mathrm{P}=0.002$, Tukey's test, $\mathrm{P}<0.05$ for shredders versus all FFGs, $\mathrm{P}>0.05$ for shredders versus scrapers) independently of daytime (FFGs versus day hours, $\mathrm{P}=0.395$, Table 3 ). While shredders represented $40 \%$ in a diel budget (mean biomass along the day), scrapers accounted for $27 \%$, and both stream functional components were mostly preyed at daylight (Fig. 2).

Although the diet had a wide range of species (40 prey taxa), only one third were dominant according to their biomass (Table 4), as fifteen food items represented $82-92 \%$ of the diet. The relative importance of the different prey in trout stomachs varied seasonally and along the day (i.e., spring sampling date) (Table 4). Among shredders, the plecopteran Klapopteryx kuscheli Illies, 1960 and the dipteran Tipula sp. were the main taxa (representing 1-23 and 4-54 \%, respectively of total prey biomass). Scrapers were mostly represented by the plecopteran Aubertoperla illiesi (Froehlich, 1960) and Notoperla archiplatae (Illies, 1958) (2-28 and 1$20 \%$, respectively) and by the ephemeropteran Meridialaris chiloeensis (Demoulin, 1955) (1-11 $\%)$. On the other hand, collectors were dominated by the filter-feeder Simulium sp. (1$14 \%)$

\section{TABLE 2}

Summary of the two-way ANOVA of O. mykiss stomach contents (aquatic versus terrestrial prey) among seasons and among time of the day.

Resultados del ANDEVA de dos vías del contenido estomacal de O. mykiss (presas acuáticas versus terrestres) para las estaciones del año y para las horas del día.

\begin{tabular}{|c|c|c|c|c|c|}
\hline & Degree of freedom & Sum of square & Mean square & F-ratio & P-value \\
\hline \multicolumn{6}{|c|}{ Total numbers per fish } \\
\hline Season & 3 & $4,756.503$ & $1,585.501$ & 17.778 & $<0.001$ \\
\hline Prey type & 1 & $13,297.090$ & $13,297.090$ & 149.095 & $<0.001$ \\
\hline Interaction & 3 & $3,968.187$ & $1,322.729$ & 14.831 & $<0.001$ \\
\hline \multicolumn{6}{|c|}{ Total biomass per fish } \\
\hline Season & 3 & $7,466.518$ & $2,488.839$ & 12.521 & $<0.001$ \\
\hline Prey type & 1 & $15,715.030$ & $15,715.030$ & 79.058 & $<0.001$ \\
\hline Interaction & 3 & $6,592.617$ & $2,197.539$ & 11.055 & $<0.001$ \\
\hline \multicolumn{6}{|c|}{ Total number per fish } \\
\hline Day hours & 3 & $1,262.704$ & 420.901 & 3.453 & 0.019 \\
\hline Prey type & 1 & $9,815.319$ & $9,815.319$ & 80.535 & $<0.001$ \\
\hline Interaction & 3 & $1,109.294$ & 369.765 & 3.034 & 0.033 \\
\hline \multicolumn{6}{|c|}{ Total biomass per fish } \\
\hline Day hours & 3 & $2,586.890$ & 862.297 & 3.333 & 0.022 \\
\hline Prey type & 1 & $7,731.388$ & $7,731.388$ & 29.886 & $<0.001$ \\
\hline Interaction & 3 & $1,892.044$ & 630.681 & 2.438 & $0.069 \mathrm{~ns}$ \\
\hline
\end{tabular}




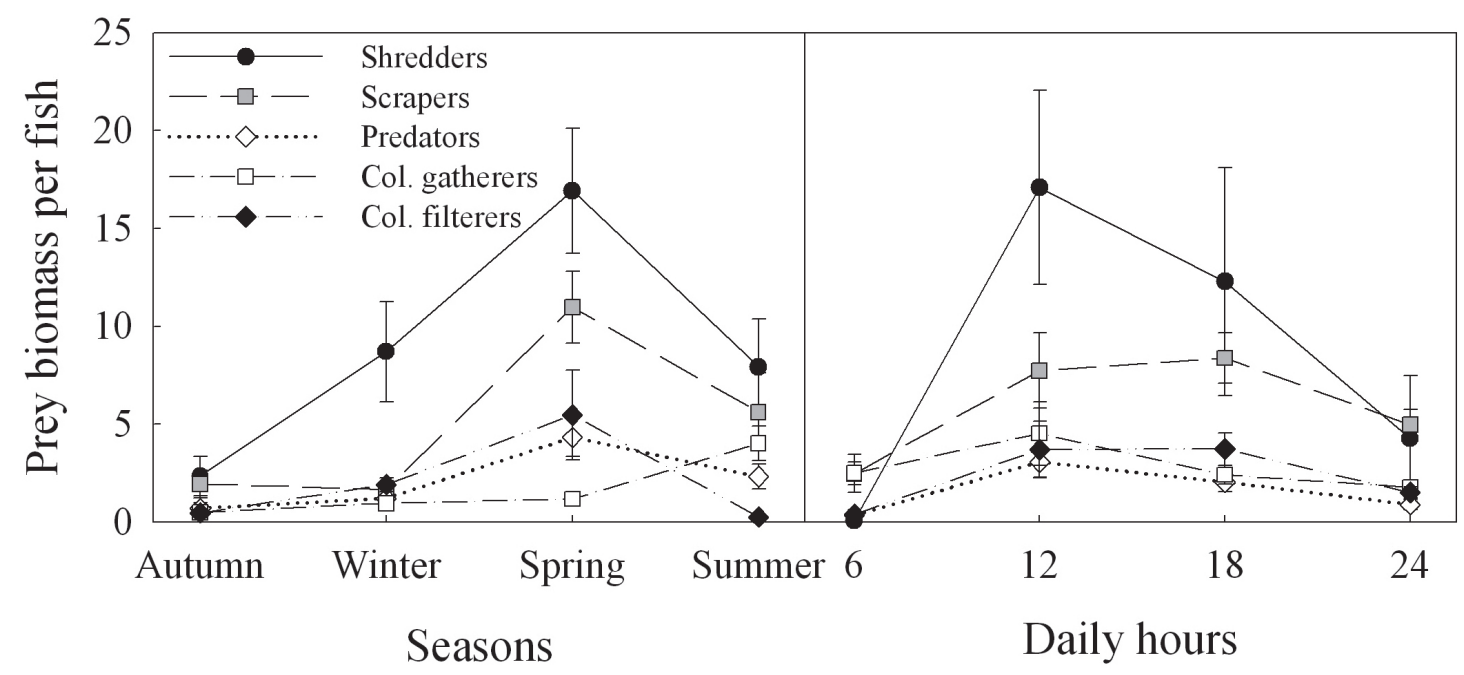

Fig. 1: Seasonal and diel variations in biomass and number per fish of aquatic and terrestrial prey. Data represent mean \pm SE.

Variación estacional y diaria en el número y la biomasa por pez de las presas terrestres y acuáticas. Los datos corresponden a medias \pm EE.

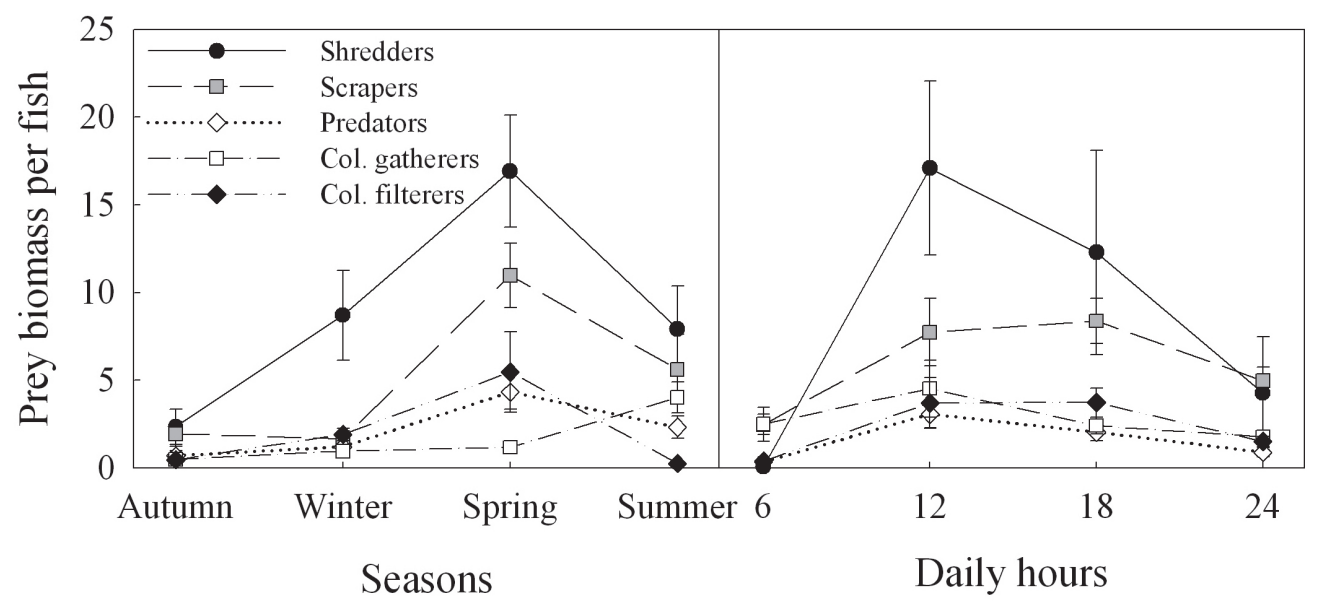

Fig. 2: Seasonal and diel variations in dry biomass of FFGs (Shredders, Scrapers, Predators, Collector Gatherers and Collector Filters) in stomach contents of rainbow trout in Challhuaco stream. Data represent mean $\pm \mathrm{SE}$.

Variación estacional y diaria en la biomasa seca de los GFAs (Fragmentadores, Raspadores, Depredadores, Colectores Recolectores y Colectores Filtradores) en los contenidos estomacales de la trucha arco iris en el arroyo Challhuaco. Los datos corresponden a medias \pm EE. 
TABLE 3

Summary of the two-way ANOVA of O. mykiss stomach content (Shredders, Scrapers, Predators, Collector Gatherers and Collector Filterers) among seasons and among time of the day.

Resultados del ANDEVA de dos vías entre el contenido estomacal de O. mykiss (Fragmentadores, Raspadores, Depredadores, Colectores Recolectores y Colectores Filtradores) para las estaciones del año y para las horas del día.

$\begin{array}{lllll}\text { Degree of freedom } & \text { Sum of square } & \text { Mean square } & \text { F-ratio } & \text { P-value }\end{array}$

Total biomass per fish

$\begin{array}{lccccc}\text { Season } & 3 & 3,169.849 & 1,056.616 & 14.004 & <0.001 \\ \text { FFGs } & 4 & 3,553.100 & 888.275 & 11.773 & <0.001 \\ \text { Interaction } & 12 & 2,269.193 & 189.099 & 2.506 & 0.003\end{array}$

Total biomass per fish

\begin{tabular}{lccccc} 
Day hours & 3 & $1,440.397$ & 480.132 & 4.922 & 0.002 \\
FFGs & 4 & $1,764.530$ & 441.133 & 4.522 & 0.002 \\
Interaction & 12 & $1,240.856$ & 103.405 & 1.060 & $0.395 \mathrm{~ns}$ \\
\hline
\end{tabular}

TABLE 4

Seasonal and diel (single spring date) changes in mean dry mass $( \pm$ SE) of the major food items. References: - indicates $<0.1 \mathrm{mg}$. SHR $=$ shredders, $\mathrm{SCR}=$ scrapers, $\mathrm{CGH}=$ collector gatherers, $\mathrm{CFI}=$ collector filterers .

Cambio estacional y diario (muestreo de primavera) en la biomasa seca media ( \pm Error estándar) de los principales ítemes alimentarios: - indica $<0.1 \mathrm{mg}$. SHR $=$ Fragmentadores, $\mathrm{SCR}=$ Raspadores, $\mathrm{CGH}=$ Colectores recolectores, $\mathrm{CFI}=$ Colectores filtradores.

\begin{tabular}{|c|c|c|c|c|c|c|c|c|}
\hline & Summer & Autumn & Winter & Spring & $6 \mathrm{~h}$ & $12 \mathrm{~h}$ & $18 \mathrm{~h}$ & $24 \mathrm{~h}$ \\
\hline \multicolumn{9}{|l|}{ Aquatic fauna } \\
\hline Klapopteryx kuscheli (SHR) & $3.8(1.9)$ & $1.4(1.0)$ & - & $0.4(0.1)$ & - & $9.6(1.7)$ & $3.7(0.2)$ & $0.9(0.6)$ \\
\hline Tipula sp. (SHR) & $2.3(1.6)$ & - & $7.8(3.5)$ & $15.1(5,0)$ & - & $6.7(4.0)$ & $2.2(0.2)$ & $3.1(1.1)$ \\
\hline Myotrichia murina (Schmid, 1955) (SHR) & $0.4(0.1)$ & $0.3(0.2)$ & $0.4(0.2)$ & $1.2(0.5)$ & - & $0.8(0.4)$ & $1.0(0.1)$ & $0.1(0.1)$ \\
\hline Aubertoperla illiesi (SCR) & - & $0.2(0.1)$ & $0.7(0.1)$ & $4.1(0.5)$ & $2.5(0.6)$ & $3.9(0.7)$ & $5.9(1.0)$ & $4.3(0.8)$ \\
\hline Notoperla archiplatae (SCR) & $3.4(1.9)$ & $1.2(0.7)$ & - & $0.3(0.1)$ & - & $0.3(0.2)$ & - & $0.7(0.4)$ \\
\hline Metamonius anceps (Eaton, 1883) (SCR) & $0.4(0.2)$ & - & - & $0.8(0.3)$ & - & $3.2(1.2)$ & $1.1(0.4)$ & - \\
\hline Meridialaris chiloeensis (SCR) & $1.6(0.5)$ & $0.6(0.2$ & $0.3(0.1)$ & $2.6(0.6)$ & - & - & - & - \\
\hline Edwardsina sp. (SCR) & - & - & $0.6(0.5)$ & $3.0(0.8)$ & - & $0.3(0.2)$ & $1.1(0.8)$ & - \\
\hline Chironomidae (CGH) & $0.8(0.3)$ & - & $0.7(0.1)$ & $0.7(0.2)$ & - & $0.5(0.1)$ & $1.3(0.3)$ & $0.6(0.2)$ \\
\hline Pelurgoperla personata (CGH) & $3.1(0.8)$ & $0.2(0.1)$ & - & - & $0.1(0.1)$ & $0.2(0.1)$ & - & - \\
\hline Brachysetodes major $(\mathrm{CGH})$ & - & $0.2(0.1)$ & $0.2(0.1)$ & $0.2(0.1)$ & $2.3(1.0)$ & $3.8(1.4)$ & $1.0(0.4)$ & $1.0(0.3)$ \\
\hline Simulium sp. (CFI) & $0.3(0.1)$ & $0.5(0.2)$ & $1.9(0.4)$ & $5.5(1.6)$ & $0.4(0.2)$ & $1.9(0.4)$ & $3.7(0.8)$ & $1.4(0.3)$ \\
\hline \multicolumn{9}{|l|}{ Terrestrial fauna (all adults) } \\
\hline Coleoptera & - & - & - & $0.9(0.5)$ & - & $3.4(2.3)$ & $1.5(1.4)$ & $1.3(0.8)$ \\
\hline Diptera & - & - & - & - & - & $1.1(0.5)$ & $2.8(2.0)$ & $3.6(1.6)$ \\
\hline Hymenoptera & - & - & - & - & - & $0.2(0.1)$ & - & $0.2(0.1)$ \\
\hline
\end{tabular}


Trout selectivity on invertebrate community showed a relatively constant pattern at both functional and taxonomic units. In general, scrapers were over-preyed compared to their abundance in the environment (Fig. 3 and 4). On the contrary, shredders, predators and collector-filterers were consumed proportionally to their ambient abundance while collector-gatherers were consistently underrepresented (Fig. 3 and 4). In the diel sampling, aquatic items were preferred over terrestrial invertebrates except at midnight when they were selected even at low natural abundance (Fig. 4). Overall, trout consumed invertebrate taxa almost at their relative numeric abundance in the stream (Fig. 3 and 4) with four taxa were consistently biased from this pattern (Fig. 3 and 4). The scraper A. illiesi was overrepresented in the diet while chironomids were negatively selected by trout at any sampling occasion (Fig. 3 and 4). Exceptionally few other taxa were temporally selected (e.g., the collectors Brachysetodes major Schmid and Simulium sp.), perhaps reflecting availability related to body size or individual exposure to predation.

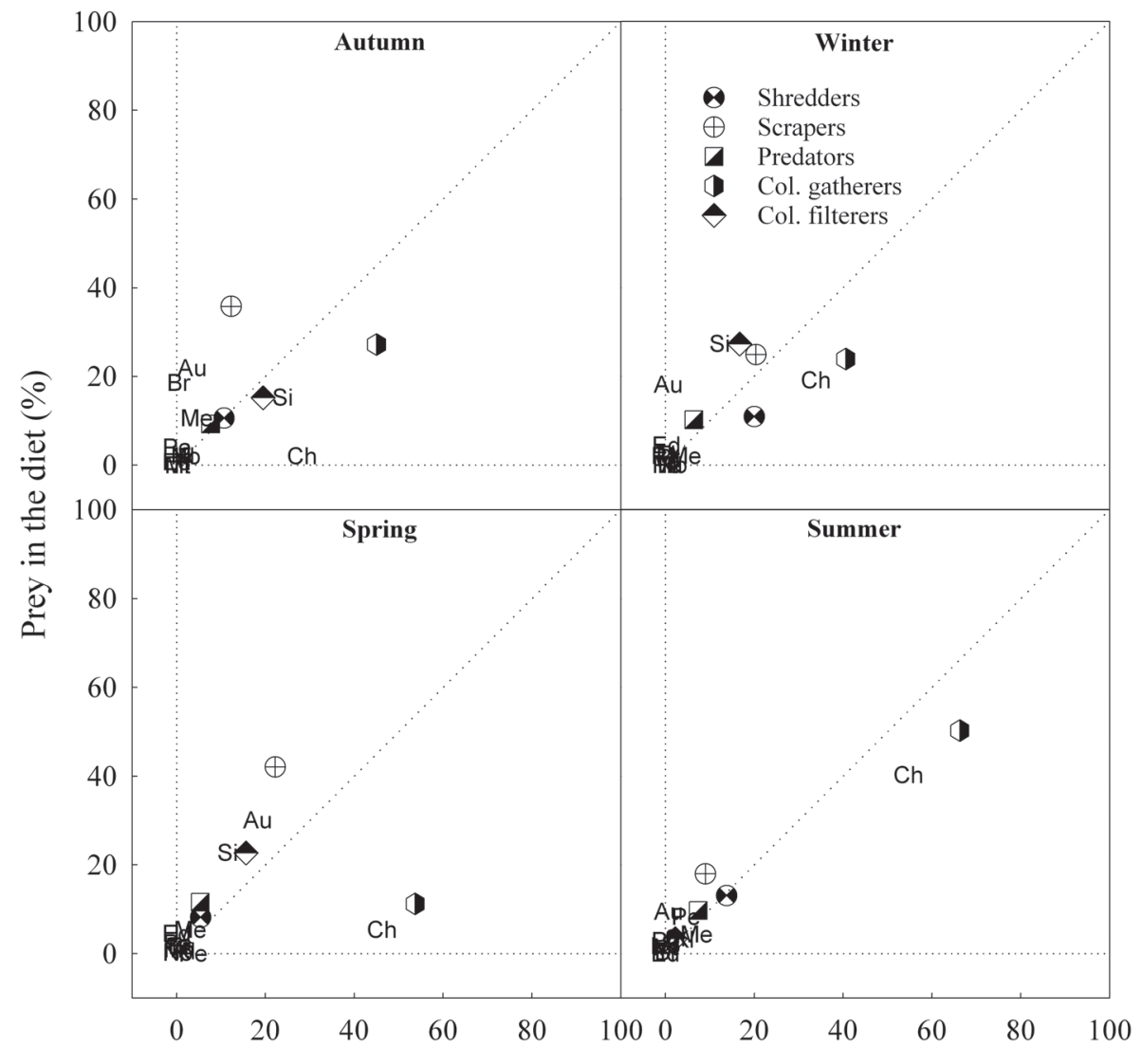

Prey in the benthic sample $(\%)$

Fig. 3: Relationship between relative composition of major prey items in stomach contents and benthic samples. $\mathrm{Kl}=K$. kuscheli, $\mathrm{Ti}=$ Tipula sp., $\mathrm{Pa}=$ M. murina, $\mathrm{Au}=A$. illiesi, $\mathrm{No}=N$. archiplatae, $\mathrm{Mf}=M$. anceps, $\mathrm{Me}=M$. chiloeensis, $\mathrm{Ed}=$ Edwardsina $\mathrm{sp} ., \mathrm{Ch}=$ Chironomidae, $\mathrm{Pe}=$ $P$. personata, $\mathrm{Br}=B$. major, $\mathrm{Si}=$ Simulium sp. Symbols represent FFGs. Dotted line indicates equal proportion of prey item in gut content and benthic samples.

Relaciones entre la composición relativa de los mayores ítemes presa en los contenidos estomacales y las muestras bentónicas. $\mathrm{Kl}=K$. kuscheli, $\mathrm{Ti}=$ Tipula $\mathrm{sp} ., \mathrm{Pa}=M$. murina, $\mathrm{Au}=$ A. illiesi, $\mathrm{No}=N$. archiplatae, $\mathrm{Mf}=M$. anceps, $\mathrm{Me}=$ $M$. chiloeensis, $\mathrm{Ed}=$ Edwardsina $\mathrm{sp} ., \mathrm{Ch}=$ Chironomidae, $\mathrm{Pe}=P$. personata, $\mathrm{Br}=B$. major, $\mathrm{Si}=$ Simulium $\mathrm{sp} . \mathrm{Los}$ símbolos representan los grupos funcionales alimentarios. La línea punteada indica una proporción igual de ítemes presas en los estómagos y en las muestras bentónicas. 


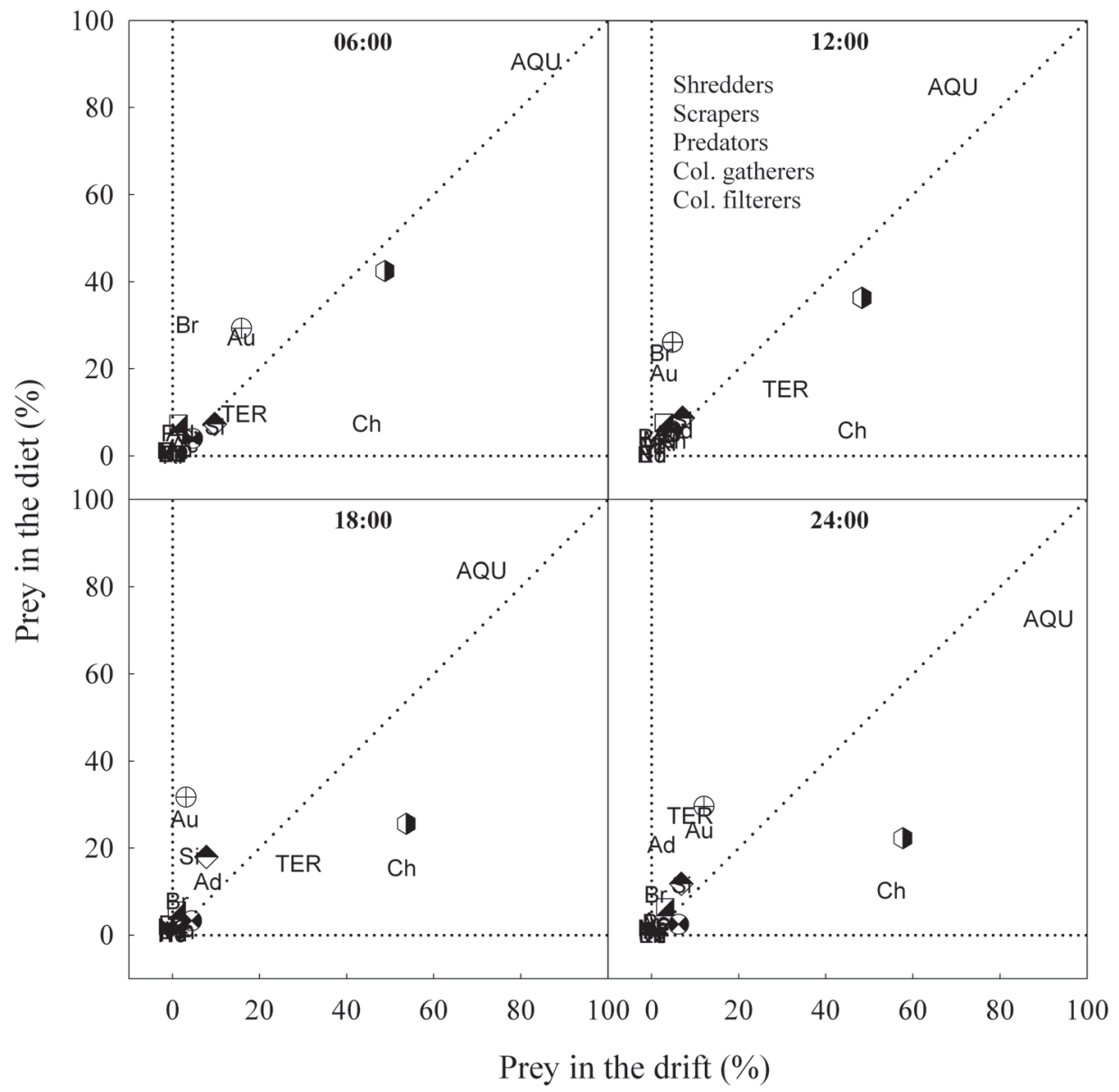

Fig. 4: Relationship between relative composition of major prey items in stomach contents and drift samples. References: TER $=$ terrestrial items, $\mathrm{AQU}=$ aquatic items, Ac $=$ Adult Coleoptera, $\mathrm{Ad}=$ Adult Diptera, $\mathrm{Ah}=$ Adult Hymenoptera; other references as in Fig. 3.

Relaciones entre la composición relativa de los mayores items presa en los contenidos estomacales y las muestras de deriva. Referencias: TER = ítemes terrestres, $\mathrm{AQU}=$ ítemes acuáticos Ac $=$ Adultos Coleoptera, $\mathrm{Ad}=\mathrm{Adultos}$ Diptera, $\mathrm{Ah}$ $=$ Adultos Hymenoptera; los restantes como en la Fig. 3 .

\section{DISCUSSION}

The analysis of fish diets and their feeding habits are good tools for understanding trophic interactions and food web dynamics (Garvey et al. 1998, Vander Zanden et al. 2000). The importance of terrestrial invertebrates in the diet of stream fishes has been confirmed in early studies (McLennan \& MacMillan 1984, Garman 1991), particularly for salmonids (Glova \& Sagar 1991) which consequently reduced predation pressure on aquatic invertebrates (Nakano et al. 1999, Englund \& Polhemus 2001). High abundance of terrestrial fauna in the guts of salmonids could reflect the scarcity of aquatic prey in the stream (Pedley \&
Jones 1978) or the abundance of terrestrial prey inputs from their canopied surroundings (Nakano et al. 1999). Both patterns enforce high connectivity between terrestrial and aquatic systems (Cloe \& Garman 1996). In our studied stream, terrestrial invertebrates bloomed during spring-summer period (riparian strips and emergence trap samples, Buria \& Albariño (unpublished data) and they were abundant in our drift spring sampling (up to 30 $\%$ of total invertebrates collected, Fig. 4). We had hypothesized that diet would change during this period to include terrestrial prey as a major component. However, terrestrial invertebrates constituted a minor proportion of the diet year round. Palma et al. (2002) found similar results 
in rainbow trout populations from low and midorder streams of the Coastal Range in central Chile. On the contrary, in North America Hunt (1975) and McLemore \& Meehan (1988) found that this trout species mainly foraged on terrestrial items occasionally. Invertebrate communities in Andean Patagonia headwater streams are characterized by a set of large bodied species (e.g., plecopterans, trichopterans, dipterans) strongly preyed by trout (Buria et al. 2007). Therefore, the vulnerability to predation of large aquatic specimens might reduce the relative significance of terrestrial items for trout diet. Fish foraging varies seasonally and along the day as abiotic factors (e.g., water temperature, light, water current) regulate metabolic demands and predation behavior (Shepard \& Mills 1996, Kreivi et al. 1999, Elliott \& Hurley 2000) at both temporal scales. In our study, rainbow trout fed more intensively in spring and summer and particularly during daytime. Biomass of aquatic prey in the diet reached a maximum in spring, representing a threefold increase compared with autumn levels. Overall, aquatic prey abundance in stomachs was significantly higher in spring compared to the remaining seasons, while terrestrial prey was significantly lower and homogeneous year round. Perhaps higher availability of larger aquatic prey (Buria et al. 2007) added to increasing invertebrate drift (Hieber et al. 2003) and longer daylight range occurring in spring have determined the observed higher prey abundance in stomachs. Reimers (1963) and Wipfli (1997) also found an increase in trout activity from winter to spring with aquatic large invertebrate instars dominating the diet as a consequence of water temperature gradual rising. On the contrary, decreasing temperatures caused a drop in foraging rates, due to the slower rate of digestion and general reductions in metabolic rates (Higgins \& Talbot 1985). Thus, seasonal changes in water temperature can result in considerable variation in predator activity (Dwyer \& Kramer 1975). During the study, water temperature ranged from 4 to $7{ }^{\circ} \mathrm{C}$ autumn-winter indicating rainbow trout had low metabolism and explaining our low prey numbers in trout stomachs. In addition, current velocity reduces the reaction distance of foraging salmonids (Hughes \& Dill 1990) negatively affecting predation success (O’Brien \& Showalter 1993). Patagonian streams are characterized by a bimodal hydrological regime dominated by a rainy autumn and a snowmelt peaks, with base discharge occurring in late summer. For instance, during our study in Challhuaco stream current velocity increased from $0.3 \mathrm{~m} \mathrm{~s}^{-1}$ in late summer, to near $0.9 \mathrm{~m} \mathrm{~s}^{-1}$ in late winter, surely affecting predation success. In a diel basis, both biomass and number of aquatic prey were significantly higher than terrestrial invertebrates. However, only prey number of aquatic items (subrogate of successful predatory encounters) was higher during daylight confirming its visually dependent behavior, as previously found in other studies (Elliott 1973, Metz 1974, Angradi \& Griffith 1990). Besides, less efficient encounters under dark conditions were compensated with similar prey biomass in stomachs by predation on larger aquatic specimens. In consequence, a combination of factors (prey abundance and activity, water temperature, current velocity, and daylight) acted together regulating rainbow trout foraging activity and success.

The broad taxonomic spectrum observed in the trout diet including 40 invertebrate prey species would have resulted from its opportunistic feeding behavior. Cannibalism has been widely observed in salmonids, particularly in rainbow trout, where larger specimens prey on smaller ones (e.g., Elliot 1973, Kido et al. 1999). On the contrary, Palma et al. (2002) reported absence of small congeners as prey of rainbow trout in a Chilean stream. Similarly, we did not find evidence of cannibalism or remains of other vertebrates in trout diet of Challhuaco stream. For most of the community the diet reflected the numeric abundance of invertebrates present in the benthos and drift (Fig. 3 and 4). However, some taxa were consumed at higher or lower numbers than expected and this influenced the relative importance of FFGs in the diet. As expected in detritus-based systems (low order heavy canopied streams) (Vannote et al. 1980), aquatic shredders in Challhuaco stream dominated benthic community biomass year round (Albariño \& Díaz Villanueva 2006, Buria et al. 2007). Shredders were the most important item in trout stomachs (\% biomass) (Fig. 2) and they were consumed according to natural abundance (Fig. 3 and 4). Scrapers represented 
the second FFG in trout diet and during summer and autumn the diet was co-dominated by shredders and scrapers (40 and $30 \%$ of relative biomass in stomachs, respectively) (Fig. 2). The absence of trout selectivity over shredders (Fig. 3 and 4) might be associated with their habits since shredders feed on leaf litter trapped underneath benthic substrates (Albariño \& Balseiro 2002), a microhabitat commonly mentioned as refuge against fish predation (Tippets \& Moyle 1978, Culp 1986, Bechara et al. 1992, Bechara et al. 1993). On the other hand, scrapers, which obtain food from stone surfaces, are more exposed and vulnerable to predation from visual feeding fish (Culp \& Scrimgeour 1993). This fact may explain our results on the positive trout selectivity on scrapers (Fig. 3 and 4). Overall, differences in the patterns associated to those FFGs in terms of biomass and numbers arise from the larger body sizes attained by shredders. On the other hand, chironomids, which were very abundant in our study, were negatively selected by trout; likely as a consequence of their small size compared to other invertebrate prey. Therefore, body size, functional habit and population abundance of prey were the traits determining diet composition of rainbow trout.

The impact of fish predation on stream arthropod assemblages has long been debated (Wooster \& Sih 1995, Dahl \& Greenberg 1996) and it is not obvious why the effect of salmonids on benthic prey is so variable (Dahl 1998). The consumption of large amounts of terrestrial invertebrates may potentially reduce the impact of trout on benthic prey (Dahl 1998, Nakano et al. 1999). Our data does not support the idea that terrestrial invertebrates significantly subsidize trout diet. Thus, the linkage between the aquatic and terrestrial ecosystem was not directly through predation of terrestrial insects by fish. On the contrary, as rainbow trout fed mainly on shredders the role of allochthonous detritus inputs is emphasized. Shredders are important biotic processors of plant detritus, contributing to matter and nutrient cycling pathways in streams (Cummins 1973, Zhang et al. 2004). In our study, scrapers were the secondary prey group supplying in part matter and energy to this rainbow trout population. As allochthonous invertebrate preys did not significantly supply rainbow trout diet, we cannot expect a predation pressure release on the stream community. Therefore top-down effects on the structure and functioning of aquatic food webs in these systems may be strong as a consequence of fish introductions.

\section{ACKNOWLEDGMENTS}

We thank anonymous reviewers for their comments and suggestions on an earlier version of the manuscript. This work was supported by the CONICET (Grant \#6507) and FONCYT (Grant \#01-13395).

\section{LITERATURE CITED}

ALBARIÑO RJ \& EG BALSEIRO (2002) Leaf litter breakdown in Patagonian streams: native vs. exotic trees and the effect of invertebrate size. Aquatic Conservation: Marine and Freshwater Ecosystems 12: 181-192.

ALBARIÑO RJ \& V DIAZ VILLANUEVA (2006) Feeding ecology of two Plecopterans in low order Andean-Patagonian streams. International Review of Hydrobiology 91: 122-135.

ANGRADI TR \& JS GRIFFITH (1990) Diel feeding chronology and diet selection of rainbow trout (Oncorhynchus mykiss) in Henry's Fork of the Snake River, Idaho. Canadian Journal of Fisheries and Aquatic Sciences 47: 199-209.

BARROS VR, VH CORDON, CL MOYANO, RJ MENDEZ, JC FORQUERA \& O PICIO (1983) Cartas de precipitación de la zona oeste de las provincias de Río Negro y Neuquén. Facultad Ciencias Agrarias, Universidad Nacional del Comahue, Cinco Saltos, Río Negro, Argentina. 40 pp.

BAXTER CV, KD FAUSCH \& WC SAUNDERS (2005) Tangled webs: reciprocal flows of invertebrate prey link streams and riparian zones. Freshwater Biology 50: 201-220.

BECHARA JA, G MOREAU \& D PLANAS (1992) Topdown effects of brook trout (Salvelinus fontinalis) in a boreal forest stream. Canadian Journal of Fisheries and Aquatic Sciences 49: 2093-2103.

BECHARA JA, G MOREAU \& L HARE (1993) The impact of brook trout (Salvelinus fontinalis) on an experimental stream benthic community: the role of spatial and size refugia. Journal of Animal Ecology 62: 451-464

BURIA LM, RJ ALBARIÑO, V DÍAZ VILLANUEVA, B MODENUTTI \& E BALSEIRO (2007) Impact of exotic rainbow trout on the benthic macroinvertebrate community from AndeanPatagonian headwater streams. Fundamental and Applied Limnology Archiv Für Hydrobiologie 168: 145-154.

CLOE WW \& GC GARMAN (1996) The energetic importance of terrestrial arthropod inputs to three warm-water streams. Freshwater Biology 36: 105114.

CULP JM (1986) Experimental evidence that stream macroinvertebrate community structure is 
unaffected by different densities of coho salmon fry. Journal of the North American Benthological Society 5 : 140-149.

CULP JM \& GJ SCRIMGEOUR (1993) Size-dependent diel foraging periodicity of a mayfly grazer in streams with and without fish. Oikos 68: 242-250.

CUMMINS KW (1973) Trophic relations of aquatic insects. Annual Review of Entomology 18: 183206.

CUMMINS KW, MA WILZBACH, DM GATES, JB PERRY \& TW TALIAFERRO (1989) Shredders and riparian vegetation. BioScience 39: 24-30.

CUMMINS KW, CE CUSHING \& GW MINSHALL (1995) Introduction: an overview of stream ecosystems. En: Cushing CE, Cummins KW \& GW Minshall (eds) River and stream ecosystems: 1-8. Elsevier, New York, USA.

DAHL J (1998) Effects of a benthivorous and drift-feeding fish on benthic stream assemblage. Oecologia 116: 426-432.

DAHL J \& L GREENBERG (1996) Impact on stream benthic prey by benthic vs. drift feeding predators: a meta-analysis. Oikos 77: 177-181.

DWYER WP \& RH KRAMER (1975) The influence of temperature on scope of activity in cutthroat trout, Salmo clarki. Transactions of the American Fisheries Society 104: 552-554.

ELLIOTT JM (1973) The food of brown and rainbow trout (Salmo trutta and $S$. gairdneri) in relation to the abundance of drifting invertebrates in a mountain stream. Oecologia 12: 329-347.

ELLIOTT JM \& MA HURLEY (2000) Optimum energy intake and gross efficiency of energy conversion for brown trout, Salmo trutta, feeding on invertebrates or fish. Freshwater Biology 44: 605-615.

ENGLUND RA \& DA POLHEMUS (2001) Evaluating the effects of introduced rainbow trout (Oncorhynchus mykiss) on native stream insects on Kauai Island, Hawaii. Journal of Insect Conservation 5: 265-281.

GARMAN GC (1991) Use of terrestrial arthropod prey by a stream-dwelling cyprinid fish. Environmental Biology of Fishes 30: 325-331.

GARVEY JE, JE RETTIG, RA STEIN, DM LODGE \& SP KLOSIEWSKI (1998) Scale-dependent associations among fish predation, littoral habitat, and distributions of crayfish species. Ecology 84: 33393348.

GLOVA GJ \& PM SAGAR (1991) Dietary and spatial overlap between stream populations of a native and two introduced fish species in New Zealand. Australian Journal of Marine and Freshwater Research 42: 423-433.

GREIG HS \& AR MCINTOSH (2006) Indirect effects of predatory trout on organic matter processing in detritus-based stream food webs. Oikos 112: 31-40.

HIEBER M \& MO GESSNER (2002) Contribution of stream detrivores, fungi, and bacteria to leaf breakdown based on biomass estimates. Ecology 83: 1026-1038.

HIEBER M, CT ROBINSON \& U UEHLINGER (2003) Seasonal and diel patterns of invertebrate drift in different alpine stream types. Freshwater Ecology 48: 1078-1092.

HIGGINS PJ \& C TALBOT (1985) Growth and feeding in juvenile Atlantic salmon. In: Cowey $\mathrm{CB}$, AM Mackie \& JG Bell (eds) Nutrition and feeding in fish: 243-263. Academic Press, London, United Kingdom.

HUGHES NF \& LM DILL (1990) Position choice by driftfeeding salmonids: model and test for Arctic grayling (Thymallus arcticus) in subarctic mountain streams, interior Alaska. Canadian Journal of Fisheries and Aquatic Science 47: 2039-2048.

HUNT RL (1975) Food relations and behavior of salmonid fishes. In: Hasler AD (ed) Coupling of land and water systems: 137-151. Springer-Verlag, New York, New York, USA.

HURLBERT SH, W LOAYZA \& T MORENO (1986) Fish-flamingo-plankton interactions in the Peruvian Andes. Limnology and Oceanography 31: 457-468.

HURYN AD (1998) Ecosystem level evidence for topdown and bottom-up control of production in a grassland stream system. Oecologia 115: 173-183.

KAWAGUCHI Y \& S NAKANO (2001) Contribution of terrestrial invertebrates to the annual resource budget for salmonids in forest and grassland reaches of a headwater stream. Freshwater Biology 46: 303-316.

KIDO MH, DE HEACOCK \& A ASQUITH (1999) Alien rainbow trout (Oncorhynchus mykiss) (Salmoniformes: Salmonidae) diet in Hawaiian stream. Pacific Science 53: 242-251.

KREIVI P, T MUOTKA, A HUUSKO, A MÄKI-PETÄYS A HUHTA \& K MEISSNER (1999) Diel feeding periodicity, daily ration and prey selectivity in juvenile brown trout in a subarctic river. Journal of Fish Biology 55: 553-571.

LEMKE MJ \& SH BOWEN (1998) The nutritional value of organic detrital aggregate in the diet of fathead minnows. Freshwater Biology 39: 447-453.

MCLEMORE CE \& WR MEEHAN (1988) Invertebrates of Meadow creek, Union Country, Oregon, and their use as food by trout. United States Department of Agriculture Forestry Service Research Paper PNW-RP-394 (USA). 13 pp.

MCLENNAN JA \& BWH MACMILLAN (1984) The food of rainbow and brown trout in the Mohaka and other rivers of Hawke's Bay, New Zealand. New Zealand Journal of Marine and Freshwater Research 18: $143-158$.

MERRITT RW \& KW CUMMINS (1996) An introduction to the aquatic insects of North America. Third edition. Kendall/Hunt Publishing Company, Dubuque, Iowa, USA. $862 \mathrm{pp}$.

METZ JP (1974) Die invertebratedrift an der oberflache eines voralpenflusses und ihre selektive ausnutzung die regenbogenfurellen (Salmo gairdneri). Oecologia 14: 247-267.

MISERENDINO ML (2001) Length-mass relationships for macroinvertebrates in freshwater environments of Patagonia (Argentina). Ecología Austral (Argentina) 11: 3-8

NAIMAN RJ \& H DECAMPS (1997) The ecology of interfaces: riparian zones. Annual Review of Ecology and Systematics 28: 621-658.

NAKANO S, H MIYASAKA \& N KUHARA (1999) Terrestrial-aquatic linkages: riparian arthropod inputs alter trophic cascades in a stream food web. Ecology 80: 2435-2441

NAKANO S \& M MURAKAMI (2001) Reciprocal subsidies: dynamic interdependence between terrestrial and aquatic food webs. Proceedings of the National Academy of Science USA 98: 166170 .

O'BRIEN WJ \& JJ SHOWALTER (1993) Effects of current velocity and suspended debris on the drift feeding of artic grayling. Transactions of the American Fisheries Society 122: 609-615.

PALMA A, R FIGUEROA, VH RUIZ, E ARAYA \& P BERRÍOS (2002) Composición de la dieta de 
Oncorhynchus mykiss (Walbaum 1792) (Pisces: Salmonidae) en un sistema fluvial de baja intervención antrópica: estero Nonguen, VIII Region, Chile. Gayana 66: 129-139.

PASCUAL M, P MACCHI, J URBANSKI, F MARCOS, C RIVA ROSSI, M NOVARA \& P DELL'ARCIPRETE (2002) Evaluating potential effects of exotic freshwater fish from incomplete species presence-absence data. Biological Invasions 4: 101-113.

PEDLEY RB \& JW JONES (1978) The comparative feeding behaviour of brown trout Salmo trutta L. and Atlantic salmon Salmo salar L. in Llyn Dwythwch, Wales. Journal of Fish Biology 12: 239256.

PETERSEN RC \& KW CUMMINS (1974) Leaf processing in a woodland stream ecosystem. Freshwater Biology 4: 343-368.

POWER ME (1990) Effects of fish on river food webs. Science 250: 411-415.

QUIRÓS R (1990) Predictors of relative fish biomass in lakes and reservoirs of Argentina. Canadian Journal of Fisheries and Aquatic Sciences 47: 928-939.

REIMERS N (1963) Body condition, water temperature, and overwinter survival. Transactions of the American Fisheries Society 92: 39-46.

SHEPARD WC \& EL MILLS (1996) Diel feeding, daily food intake, and Daphnia consumption by age-0 gizzard shad in Oneida Lake, New York Transactions of the American Fisheries Society 125: 411-421.

TIPPETS WE \& PB MOYLE (1978) Epibenthic feeding by rainbow trout (Salmo gairdneri) in the McCloud
River, California. Journal of Animal Ecology 47: 549-559

VANDER ZANDEN MJ, BJ SHUTER, NP LESTER \& JB RASMUSSEN (2000) Within and amongpopulation variation in the trophic position of a pelagic predator, lake trout (Salvelinus namaycush). Canadian Journal of Fisheries and Aquatic Sciences 57: 725-731.

VANNOTE RL, GW MINSHALL, KW CUMMINS, JR SEDELL \& CE CUSHING (1980) The river continuum concept. Canadian Journal of Fisheries and Aquatic Sciences 37: 130-137.

VELÁSQUEZ SM \& ML MISERENDINO (2003) Habitat type and macroinvertebrate assemblages in low order Patagonian streams. Archiv Für Hydrobiologie 158: 461-483.

WALLACE JB, SL EGGERT, JL MEYER \& JR WEBSTER (1997) Multiple trophic levels of a forest stream linked to terrestrial litter inputs. Science 277: 102-104.

WIPFLI MS (1997) Terrestrial invertebrates as salmonid prey and nitrogen sources in streams: contrasting old-growth and young-growth riparian forests in southeastern Alaska, USA. Canadian Journal of Fisheries and Aquatic Sciences 54: 1259-1269.

WOOSTER D \& A SIH (1995) A review of the drift and activity responses of stream prey to predator presence. Oikos 73: 3-8

ZHANG Y, JS RICHARDSON \& JN NEGISHI (2004) Detritus processing, ecosystem engineering and benthic diversity: a test of predators-omnivore interference. Journal of Animal Ecology 73: 756766. 
